\title{
Heat Shock Protein 70 and IgE as Inflammatory Mediators, are Early Predictors of Myocardial Ischemia and Recovery Markers after Coronary Artery Bypass Grafting (CABG)
}

\author{
Amal A Baalash*, Hala E Hamouda*, Bedir M Ibrahim**, \\ Ibrahim K Yassein** and Ghada M. Ismail*** \\ Departments of *Medical Biochemistry, **Cardiothoracic Surgery and \\ ***Physiology, Faculty of Medicine, Tanta University, Egypt
}

\begin{abstract}
Objective: The aim of the present study was to identify levels of heat shock protein 70 (Hsp 70), total immunoglobulin E (IgE) and matrix metalloproteinase-9 (MMP-9) before and after coronary artery bypass grafting (CABG) surgery. Method: Heat shock protein 70, IgE, MMP-9, creatine phosphokinase-MB (CPK-MB), and lactate dehydrogenase $(L D H)$ levels were measured in normal subjects $(n=20)$, and in patients with chronic stable angina pectoris who were referred for elective CABG, before and after performing CABG-surgery $(n=20)$. Result: Compared with normal subjects, increased heat shock protein 70 and IgE levels but unchanged MMP-9 level, and activities of $C P K-M B, L D H$ were found in the pre-operative patient group. Heat shock protein 70, and IgE levels in the post-operative period were significantly reduced when compared to pre-operative period. Conclusion: On the basis of these results it could be conclude that, heat shock protein 70 and IgE might be used as markers for detection of early minor myocardial damage, and coronary insufficiency with less overt damage than myocardial infarction, as significant changes in their levels appear before occurrence of in any changes in the levels of MMP-9, CPK-MB and $L D H$. Besides, heat shock protein 70, and IgE returning to the normal levels after $C A B G$ surgery, suggests that they could be helpful to evaluate the effect of $C A B G$ surgery.
\end{abstract}

\section{INTRODUCTION}

The clinical feature of myocardial ischemia correlates with a particular biochemical pattern of inflammatory system activation. Experimental models of ischemic myocardial injury indicate that the inflammatory response after the ischemic event contributes to tissue damage. ${ }^{(1)}$ So, inflammation is becoming an intriguing focus of research as a possible pathogenetic component and therapeutic target in ischemic heart disease.

Elevated values of circulating inflammatory markers, such as $\mathrm{C}$ reactive protein (CRP), serum amyloid A protein, interleukin-6, TNF and interleukin-1 receptor antagonist, are commonly found in acute coronary syndrome (ACS). It have been suggested that this systemic 
inflammatory response may be the result of the myocardial microinfarction known to occur in that case. $^{(2)}$

Heat-shock proteins (Hsps) are abundant intracellular proteins found in both prokaryotic and eukaryotic organisms. Their main function appears to be as chaperones, involved in protein folding and transport. ${ }^{(3)}$ Upregulation of the synthesis of a number of these proteins occurs upon environmental stress establishes a unique defense system to maintain cellular protein homeostasis and to ensure survival of the cell. In the cardiovascular system this enhanced protein synthesis leads a powerful increase in tolerance to such endangering situations as ischemia, hypoxia, oxidative injury, and endotoxemia. The Hsp 70 family, located in the cytosol and the nucleus of the cell, is the most conserved and the best-studied class of Hsps. Myocardial ischemia induces Hsp70 as a stress response, ${ }^{(4)}$ and Hsp 70 is increased in atrial tissue of patients with angina. $^{(5)}$ Circulating Hsp 70 is suggested as a marker of myocardial damage. In addition, Hsp70 may has a role in the inflammatory response after myocardial tissue damage. ${ }^{(6)}$

Immunoglobulin E (IgE), known primarily as a mediator of allergy, can cause platelet activation and arterial smooth muscle hyperplasia ${ }^{(7)}$. On the other hand, it has been observed that myocardial tissue damage is associated with an immunological response characterized by rise of serum immunoglobulin E (IgE). This behavior of serum $\operatorname{IgE}$ bears much resemblance to that of acute phase proteins. ${ }^{(8)}$ $\begin{array}{ccc}\text { Matrix } & \text { metalloproteinases } \\ \text { (MMPs) are a group of }\end{array}$ endopeptidases with capacity to cleave components of extracellular matrix, such as collagen and elastin. The ability to modify the tissues is important for several aspects of normal and abnormal physiology. Approximately 20 different MMPs are identified, and they can be subdivided into different groups according to which components of the extracellular matrix they degrade. Gelatinase B (MMP-9) belongs to the group of gelatinases. It readily digests the denatured collagens, and gelatins. This group of enzymes has three repeats of a type II fibronectin domain inserted in the catalytic domain, which bind to gelatin, collagens, and laminin. ${ }^{(9)}$

MMPs are secreted in a latent proform and require activation for proteolytic activity ${ }^{(\mathbf{1 0})}$.MMPs can be activated by proteinases, and reactive oxygens. Low $\mathrm{pH}$ and heat treatment can also lead to activation. (11) Recently, studies by Gu et al., ${ }^{(\mathbf{1 2})}$ have shown that NO activates proMMP-9 during cerebral ischemia by reacting with the thiol group of the cysteine switch and forming an S-nitrosylated derivative, a demonstration of the chemical activation of a proMMP in vivo.

MMP-9 is considered to play a role in the regulation of migration and proliferation of vscular smooth muscle cells (VSMCs) and modulates the cell-to-cell communication with activated surrounding cells, such as inflammatory cells, endothelial cells and VSMCs. ${ }^{(13)}$

The activity of MMPs is normally low in healthy tissue, but the expression and activity of several 
MMPs are increased in a range of pathological processes, such as inflammation and tissue repair after ischemic damage. ${ }^{(10)}$ It has been reported that concentrations of MMPs are elevated not only in affected tissue and body fluid but also in peripheral blood in some patients with cancer, liver cirrhosis or rheumatoid arthritis. ${ }^{(\mathbf{1 4}, 15)}$

These findings raise the possibility that patients with ischemic myocardial tissue would show elevated peripheral blood levels of MMPs.

Early and accurate identification of myocardial damage in patients experiencing symptoms and signs of coronary insufficiency is an important challenge. Current diagnostic tests for acute myocardial infarction (AMI) by conventional criteria are quite adequate. Evaluation of new and more-sensitive tests that can detect early minor myocardial damage posses a new problem.

Cardiac markers of "minor myocardial damages" in patients with stable angina pectoris (SAP) are not confirmed and a marker of coronary insufficiency is not well established. Besides, the recovery markers after CABG surgery are also not well established.

The present work aimed to study if heat shock protein 70, total Ig E, and MMP-9 which are proteins sharing in the inflammatory response after myocardial tissue damage and in tissue recovery, could be used as possible indicators for minor myocardial damages, and also to study if they could be used as markers for the success of CABG surgery in improving the myocardial ischemia.

\section{MATERIALS \& METHODS}

Twenty patients with chronic stable angina referred for elective CABG were included in the study. The patients had angiographically verified 3-vessels or in a few cases 2vessel disease, were $<75$ years old, and before surgery had no signs of infection. Also, emergency cases and patients undergoing combined procedures or re-operations were excluded.

The other exclusion criteria in the present study included other known diagnosed disease, acute phase fever, any allergic disease, oesinophilia or evidence of parasitic infestation in stool examination, and complications in the post-operative course.

Anesthesia and Surgical Procedure

All patients underwent a routine procedure with median sternotomy and use of CPB. Anesthesia was induced with diazepam, fentanyl, thiopental, and pancuronium and maintained with isoflurane, fentanyl, and nitrous oxide until the start of CPB. The activated clotting time was maintained $>480$ seconds during $\mathrm{CPB}$, and $\mathrm{CPB}$ was performed with flow of $2.4 \mathrm{~L} / \mathrm{min}$ per $\mathrm{m}^{2}$ body surface area. Patients were cooled down to $34^{\circ} \mathrm{C}$ at the beginning of $\mathrm{CPB}$, and active rewarming was started during the last distal coronary anastomosis. Antegrade intermittent warm blood cardioplegia was used. The left internal mammary artery was anastomosed on the left anterior descending artery, and venous grafts were used for the rest, with a mean of $2.8 \pm 0.8$ grafts per patient.

Transit-time flowmetry was done for all patients intraoperatively to 
ensure graft patency and patients who showed quantitative or qualitative low flow were excluded.

\section{Blood samples}

Two blood samples were taken from the patients, the first one was taken at the day just before the surgery and the second one was taken three weeks after CABG performance.

Another 20 healthy normal persons with matched age and sex were considered as the control group. All persons gave an informed consent for participation in the study.

Blood samples were withdrawn from subjects after overnight fasting and serum was separated for determination of the following parameters;

1. Creatine phosphokinase-MB (CPK$\mathrm{MB}$ ), and lactate dehydrogenase (LDH) using the commercially available kits;

2. Serum levels of heat shock protein70 was determined using Hsp70
ELISA kits, (StressGen Biotechnologies Corp);

3. IgE levels were determined by solid phase chemiluminescent immunometric assay, using Immulite total $\operatorname{IgE}$ kits with IMMULITE 1000 analyzer ;

4. Serum matrix metalloproteinase-9 (MMP-9) was determined using Ray Bio human MMP-9 ELISA kit (Ray Biotech. In).

Data were expressed as means \pm standard deviation (SD). A 2-tailed Student $t$ test for unpaired data was used to evaluate statistical differences between control group and the two patients groups; the significance of the intraindividual change caused by CABG was evaluated using a paired $t$ test. In all cases a difference at $\mathrm{p}<0.05$ was considered statistically significant.

\section{RESULTS}

Table (1): Demographic data and clinical characteristics of the patients undergoing elective CABG

\begin{tabular}{l|ll}
\hline Characteristic & Value & Range \\
\hline Age, years & $57.4 \pm 8.5$ & $43-66$ \\
Sex, male/female & $17 / 3$ & \\
CPB time, min & $69 \pm 17$ & $35-95$ \\
Aortic cross-clamping, min & $41 \pm 15$ & $20-67$ \\
Intubation time, hour & $5.2 \pm 1.8$ & $4.0-8.1$ \\
Postoperative in- intensive care unit stay, d & $1 \pm 0$ & one day \\
Postoperative in-hospital stay, d & $8.5 \pm 4.4$ & $6-15$ \\
\hline Distal coronary anastomoses per patient & $2.8 \pm 0.8$ & $2-4$ \\
\hline
\end{tabular}


Table (2): Serum levels of $\mathrm{Hsp} 70(\mathrm{pg} / \mathrm{ml})$ in all studied groups.

\begin{tabular}{l|lll}
\hline & Control & Pre-operative & Post-operative \\
\hline Mean + SD & $286+112$ & $895 \pm 123$ & $311 \pm 76$ \\
$\mathrm{P}$ (compared to control) & & $\mathrm{P}<0.05^{*}$ & $\mathrm{P}>0.05$ \\
$\mathrm{P}$ (compared to postoperative G) & $\mathrm{P}>0.05$ & $\mathrm{P}<0.05^{*}$ & \\
\hline
\end{tabular}

*Significant

Table (3): Serum levels of $\mathrm{IgE}(\mathrm{IU} / \mathrm{ml})$ in all studied groups.

\begin{tabular}{l|lll}
\hline & Control & Pre-operative & Post-operative \\
\hline Mean + SD & $31.6 \pm 3.4$ & $99.8 \pm 8.6$ & $37.4 \pm 5.7$ \\
$\mathrm{P}$ (compared to control) & & $\mathrm{P}<0.05^{*}$ & $\mathrm{P}>0.05$ \\
$\mathrm{P}$ (compared to postoperative G) & $\mathrm{P}>0.05$ & $\mathrm{P}<0.05^{*}$ & \\
\hline
\end{tabular}

*Significant

Table (4): Serum levels of MMP-9 (ng/ml) in all studied groups.

\begin{tabular}{l|lll}
\hline & Control & Pre-operative & Post-operative \\
\hline Mean \pm SD & $88.4 \pm 5.7$ & $95.7 \pm 6.2$ & $91.6 \pm 8.1$ \\
& & $\begin{array}{l}P>0.05 \\
P(\text { compared to control) }\end{array}$ & $\mathrm{P}>0.05$ \\
$\mathrm{P}$ (compared to postoperative G) & $\mathrm{P}>0.05$ & $\mathrm{P}>0.05$ & \\
\hline
\end{tabular}

Table (5): Serum levels of CPK-MB (IU/L) in all studied groups.

\begin{tabular}{l|lll}
\hline & Control & Pre-operative & Post-operative \\
\hline Mean \pm SD & $5.6 \pm 1.1$ & $7.2 \pm 2.5$ & $6.8 \pm 3.1$ \\
$\mathrm{P}($ compared to control) & & $\mathrm{P}>0.05$ & $\mathrm{P}>0.05$ \\
$\mathrm{P}($ compared to postoperative G) & $\mathrm{P}>0.05$ & $\mathrm{P}>0.05$ & \\
\hline
\end{tabular}

Table (6): Serum levels of LDH (IU/L) in all studied groups.

\begin{tabular}{|c|c|c|c|}
\hline & Control & Pre-operative & Post-operative \\
\hline Mean \pm SD & $229 \pm 124$ & $311 \pm 117$ & $341 \pm 126$ \\
\hline $\mathrm{P}$ (compared to control) & & $\mathrm{P}>0.05$ & $P>0.05$ \\
\hline P (compared to postoperative G) & $\mathrm{P}>0.05$ & $\mathrm{P}>0.05$ & \\
\hline
\end{tabular}




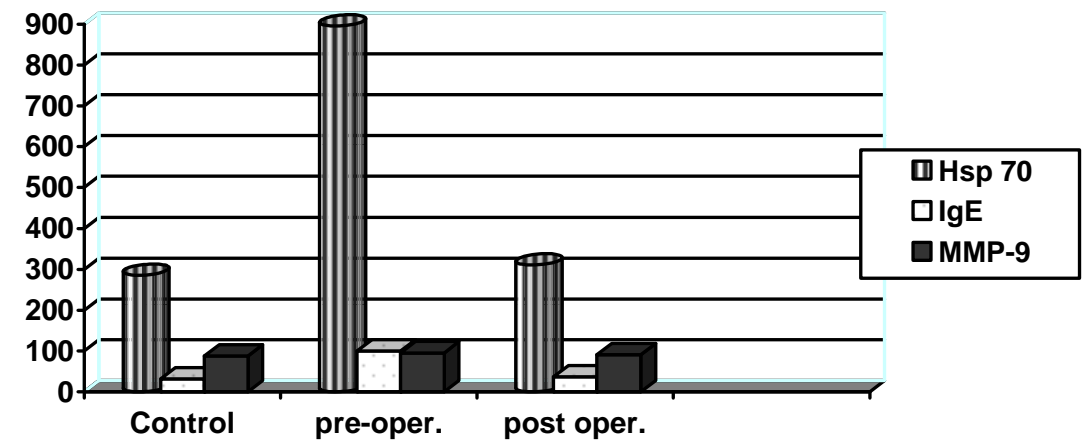

Fig. (1): Serum levels of Hsp 70, IgE, and MMP-9 in the different groups.

The demographic data and the clinical characteristics of the 20 patients who underwent the elective CABG surgery were shown in table (1)

The results of the current study revealed a significant difference in the serum levels of Hsp 70 between the pre-operative and post-operative samples of the same patient $(895 \pm 123$, \& $311 \pm 76 \mathrm{pg} / \mathrm{ml}, \mathrm{P}<0.05)$ respectively, and the pre-operative samples and the samples taken from the control persons $(895 \pm 123$ and $286 \pm 112$ $\mathrm{pg} / \mathrm{ml}, \mathrm{P}<0.05)$ respectively, however there was no statistically significant difference in its levels between both the control groups and the postoperative samples, table (2).

Table (3) shows that, total IgE levels were significantly higher in the pre-operative samples $(99.8 \pm 8.6$ $\mathrm{IU} / \mathrm{ml}$ ) when compared with both the post-operative samples $\quad(37.4 \pm 5.7$ $\mathrm{IU} / \mathrm{ml})$ and the control ones $(31.6 \pm 3.4$ $\mathrm{IU} / \mathrm{ml}$ ), and the post-operative samples didn't show a statistically significant difference when compared with the control samples.
MMP-9, CPK, and LDH levels didn't show any statistically significant difference between the three groups, tables $(4,5$, and 6).

\section{DISCUSSION}

The most important finding in the present study is the release of inducible Hsp 70 into the circulation in patients with minor myocardial damage due to coronary insufficiency, even without myocardial infarction. It has been reported that just ischemia could induce Hsp 70 in myocardial cells; Hsp70 mRNA synthesis increased when coronary flow is gradually reduced from normal to zero flow levels. Anaerobic metabolism during ischemia causes depletion of intracellular ATP which plays an important role in triggering the HSF1DNA binding activity. ${ }^{(\mathbf{1 6})}$ The heat shock transcription factor 1 (HSF1) is a transcriptional activator protein which regulates the inducible synthesis of Hsps. ${ }^{(17)}$ Once activated HSF1 monomers start to oligomerize as homotrimers, which then bind to an 
upstream sequence-specific motif, heat shock element, in the promoter of all stress-inducible Hsp genes. ${ }^{(18)}$

It has been hypothesized that anaerobic metabolism is a strong stimulus for hsp70-gene transcription, since the cessation of anaerobic metabolism is associated with complete shutdown of Hsp 70 mRNA synthesis, which may explain its return to normal levels after performing CABG surgery ${ }^{(\mathbf{1 9})}$. Also, Hsp70 synthesis could be correlated with the onset of anaerobic metabolism, but not with enzyme leakage from the tissue, ${ }^{(\mathbf{1 9})}$ and this explains the elevated Hsp 70 levels without an associated increase in the CPK-MB and LDH enzymes levels in the pre-operative ischemic patients, absence of significant changes in the cardiac enzymes levels between the different groups was in agreement with the results obtained by Batker et al. ${ }^{(20)}$ who measured CK-MB concentration in patients with or without ischemic heart disease of different etiologies. The CK-MB concentration was the same in patients with stable angina as in those without ischemic heart disease.

In another study of patients with severe stable angina, myoglobin concentration, and the cardiac enzymes, total CK activity, and CKMB concentration did not increase in relation to either spontaneous or exercise-induced ischemia, despite significant ST segment depression observed in all patients ${ }^{(21)}$.

Serum levels of IgE, also, showed a significant elevation in the preoperative samples, when compared with both post-operative and control ones, it is likely, however, that these results are applicable only to patients with severe debilitating angina pectoris those with symptoms severe enough to consider or warrant coronary bypass operation. In contrast to our results Korkmaz et al., ${ }^{(7)}$ reported that IgE levels were found to be significantly higher only in patients with unstable angina and acute myocardial infarction compared to the patients with stable angina pectoris and controls. This elevation in total serum IgE levels could be explained by the findings of Szczeklik et al., ${ }^{(8)}$ who reported that immunoglobulin E may act in humans as an acute phase protein in response to tissue injury.

The role of IgE-mediated events in the pathogenesis of cardiovascular disease may be, in part, mediated through mast cells activation, it has been observed that increased numbers of cardiac mast cells were found in human ischemic hearts. ${ }^{(22)}$ It has been suggested that in myocardial ischemia circulating IgE sensitizes mast cells in the ischemic myocardium; this facilitates release of chemical mediators. ${ }^{(8)}$ This paracrine release of cytokines regulates fibroblast phenotype and MMP activity. ${ }^{(23)}$ For example, mast cells contain substantial stores of tumor necrosis factor-alpha, a cytokine capable of inducing MMP synthesis. Also, human cardiac mast cells contain tryptase, chymase, carboxypeptidase, and cathepsin $\mathrm{G},{ }^{(24)}$ these enzymes have been implicated as being involved in the MMP activation cascade by several in vitro studies. ${ }^{(25)}$

In the current study serum levels of MMP-9 showed no significant difference between the different 
groups, the present findings are consistent with the results of the study done by Kai et al, ${ }^{(26)}$ who reported that MMP-9 level in patients with stable angina was not significantly different from that of control, also MMP-9 levels measured before, immediately after and $1 \mathrm{~h}$ after the treadmill exercise test did not change during the exercise test although exercise induced angina and typical ischemic ECG changes were documented.

The possibility that ischemia may cause release and activation of MMPs in the myocardium could not be denied. However, it must be recognized that the release and activity of MMPs involve a highly compartmentalized process and that blood MMP levels likely reflect only spillover from the interstitial compartment. $^{(27)}$ Furthermore, it is known that all MMPs require activation from precursors to attain enzymatic activity. The antibodies available for serum MMP immunoassays do not distinguish the active form of these enzymes from their proenzyme forms; therefore, so it is supposed that augmented enzymatic activity does not necessarily correspond to increase in its serum level.

Cardiac surgery, in particular cardiopulmonary bypass in coronary artery bypass grafting (CABG) and cardioplegia, has been reported to trigger myocardial inflammation and apoptosis. This surgery-related inflammatory reaction appears to be of extreme complexity with regard to its molecular, cellular and tissue mechanisms. ${ }^{(28)}$
The molecular chaperone heatshock protein (Hsp 70) has been detected both in the myocardium and in the circulation after CABG. It was reported that serum Hsp 70 reaches its peak levels by about five hours postoperatively, and returns to its normal pre-operative levels by about one day after surgery. ${ }^{(29)}$

Systemic blood levels for MMP-9 increase significantly from baseline values during $\mathrm{CABG},{ }^{(\mathbf{3 0})}$ and remain elevated until 30 minutes after cardiopulmonary bypass, MMP-9 levels tends to decrease toward normal values during the postoperative period, but there is a significant variability in this response. ${ }^{(31)}$

Also, serum IgE begins to rise shortly after the operations reaches a peak by the fifth day, and then gradually declines. ${ }^{(7)}$ In order to avoid any changes in the measured parameters that could be related to the surgical process itself, and not due to changes in the myocardial status, the second blood sample was taken three weeks after surgery.

\section{Conclusion:}

On the basis of these results it could be concluded conclude that, heat shock protein 70 and $\mathrm{IgE}$ might be used as markers for detection of early minor myocardial damage, and coronary insufficiency with less overt damage than myocardial infarction, as significant changes in their levels appear before occurrence of in any changes in the levels of MMP-9, CPK-MB and LDH. Besides, heat shock protein 70 , and $\mathrm{IgE}$ returning to the normal levels after CABG surgery, suggests that they could be helpful to evaluate the effect of CABG surgery. 


\section{REFERENCES}

1. Plebani M. (2001): Biochemical markers of cardiac damage: from efficiency to effectiveness. Clin.Chim. Acta, 311:3-7.

2. Michael R., Cusack MB., Michael S., Marber F., Pier D., Lambiase BA., Clifford A., Bucknall D.,.Simon R. and Redwood M. (2002): Systemic inflammation in unstable angina is the result of myocardial necrosis. J. Am. Coll. Cardiol., 39: 1917-1923.

3. Ohtsuka $K$. and Hata $M$. (2000): Molecular chaperone function of mammalian HSP70 and HSP40: a review. Int. J. Hyperthermia. 16: 231-245.

4. Jaattela M.(1999) : Heat shock proteins as cellular lifeguards. Ann. Med., 31: 261-271.

5. Valen G., Hansson GK., Dumitrescu A. et al.,(2000): Unstable angina activates myocardial heat shock protein 72 , endothelial nitric oxide synthase, and transcription factors NFkB and AP-1. Cardiovasc. Res., 47: 49-56.

6. Dybdahl B., Slørdahl SA., Waage A., Kierulf P., Espevik TA. and Sundan A. (2005): Myocardial ischaemia and the inflammatory response: release of heat shock protein 70 after myocardial infarction. Heart, 91: 299-304.

7. Korkmaz ME., Oto A., Saraçlar Y., Oram E., Oram A., Ugurlu S., Karamehmetoglu A. and Karaagaoglu E. (1991): Levels of $\operatorname{IgE}$ in the serum of patients with coronary arterial disease. Int. J. Cardiol., 31: 199-204.

8. Szczeklik A. and Jawień J. (1995): Humoral immune response to tissue injury, characterized by a rise in serum immunoglobulin E. Pol. Arch. Med. Wewn., 94:495-505.

9. Allan JA., Docherty AJ., Barker PJ., Huskisson NS., Reynolds JJ. And Murphy G. (1995): Binding of gelatinases $A$ and $\mathrm{B}$ to type-I collagen and other matrix components. Biochem. J., 309: 299-306.

10. Nagase H. and Woessner JF. (1999). Matrix metalloproteinases. J. Biol. Chem., 274: 21491-21494

11. Nagase H. (1997): Activation mechanisms of matrix metalloproteinases. Biol. Chem., 378: 151-160.

12. Gu Z., Kaul M., Yan B., Kridel SJ., Cui J., Strongin A., Smith JW., Liddington RC. and Lipton SA. (2002): SNitrosylation of matrix metalloproteinases: signaling pathway to neuronal cell death. Science.297: 1186-1190.

13. Dollery CM., McEwan JR., Henney AM. (1995): Matrix metalloproteases and cardiovascular disease. Circ. Res., 77: 863-868.

14. Fujimoto N., Mouri N., Iwata K., Ohuchi E. and Hayakawa T. (1993): A one-step sandwich enzyme immunoassay for human matrix metalloprotease $2(72-\mathrm{kDa}$ gelatinase/type IV collagenase) using monoclonal antibodies. Clinica Chimica Acta. 221: 91103. 
15. Fujimoto N., Hosokawa N., Iwata K., Shinya T., Okada Y. and Hayakawa T.(1994): A one-step sandwich enzyme immuno assay for inactive precursor and complexed forms of human matrix metalloprotease 9 (92 kDa gelatinase/type IV collagenase, gelatinase B) using monoclonal antibodies. Clinica Chimica Acta. 231: 79-88.

16. Benjamin IJ., Horie S., Greenberg ML., Alpern RJ. and Williams RS.(1992): Induction of stress proteins in cultured myogenic cells: molecular signals for the activation of heat shock transcription factor during ischemia. J. Clin. Invest., 89: 1685-1689.

17. Wu C. (1995): Heat shock transcription factors: structure and regulation. Ann. Rev. Cell Dev. Biol., 11: 441-469.

18. Amin J., Ananthan J. and Voellmy R. (1988): Key features of heat shock regulatory elements. Mol. Cell Biol.,8: 3761-3769.

19. Knowlton AA., Eberli FR., Brecher P., Romo GM., Owen A. and Apstein CS.(1991): A single myocardial stretch or decreased systolic fiber shortening stimulates the expression of heat-shock protein 70 in the isolated, erythrocyte perfused rabbit heart. J. Clin. Invest., 88: 2018-2025.

20. Batker HE., Ravkilde J., Sogaard P., Jorgensen PJ.,Horder M. and Thygesen K. (1991): Gradation of unstable angina based on a sensitive immunoassay for serum creatine kinase MB. Br. Heart J.,65: 7276.

21. Norregaard-Hansen K., Egstrup K., Nielson JR, et al.,(1992): Lack of indication of myocardial cell damage after myocardial ischaemia in patients with severe stable angina. Eur. Heart J., 13: 188-193.

22. Dixon IM., Ju H., Reid NL., Scammell-La FT., Werner JP. and Jasmin G.(1997): Cardiac collagen remodeling in the cardiomyopathic Syrian hamster and the effect of losartan. J. Mol. Cell Cardiol., 29: 1837-1850.

23. De Almeida A., Mustin D., Forman MF., Brower GL., Janicki JS. and Carver W (2002): Effects of mast cells on the behavior of isolated heart fibroblasts: modulation of collagen remodeling and gene expression. J. Cell Physiol., 191:51-59.

24. PatellaV., de Crescenzo G., Ciccarelli A., Marinò I., Adt M. and Marone G.(1995): Human heart mast cells: a definitive case of mast cell heterogeneity. Int Arch Allergy Immunol., 106: 386-393.

25. Nagase H. (1997): Activation mechanisms of matrix metalloproteinases. J.Biol. Chem., 378: 151-160.

26. Kai H., Ikeda H., Yasukawa H., Kai M., Seki Y., Kuwahara F., Ueno $T$. and Imaizumi $T$. (1998): Peripheral blood levels of matrix metalloproteases-2 and -9 are elevated in patients with acute coronary syndromes. J. Am. Coll. Cardiol., 32:368-372. 
27. Bremer C, Tung C-H, Weissleder R. (2001): In vivo molecular target assessment of matrix metalloproteinase inhibition. Nat. Med., 7: 743-748.

28. Czerny M., Baumer H., Kilo J., et al. (2000): Inflammatory response and myocardial injury following coronary artery bypass grafting with or without cardiopulmonary bypass. Eur. J. Cardiothorac Surg., 17: 737-742.

29. Dybdahl B., Wahba A., Lien E., Flo T., Waage A., Qureshi N., Sellevold O.and Sundan T. (2002): Inflammatory response after open heart surgery: release of heat-shock protein 70 and signaling through toll-like receptor-4. Circulation 105: 685 690.

30. Lalu M., Pasini E., Schulze C., Vivaldi M., Vivaldi G., Bachetti T.and Schulz R.(2005): Ischaemia-reperfusion injury activates matrix metalloproteinases in the human heart. European Heart Journal 26: 27-35

31. Joffs C., Gunasinghe HR., Multani MM., Dorman BH., Kratz JM., Crumbley AJ., Crawford FA. and Spinale FG. (2001): Cardiopulmonary bypass induces the synthesis and release of matrix metallo-proteinases. Ann. Thorac Surg., 71:15181523. 


\section{استخدام وسائط اللألتهاب بروتين الصدمة الحرارية V و الجلوبيولين

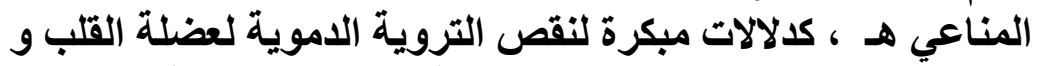 كمؤشر لنجاح عمليات زراعة الثرائن ايين التاجية}

* أمل أحمد بعلث ، * هالة السيد حمودة، ، **بدير مصطفى ابر/هيم،

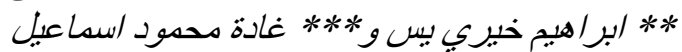

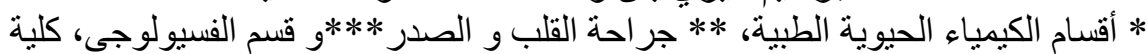

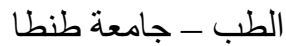

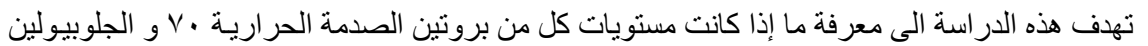

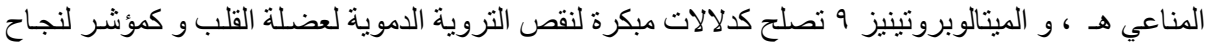
عليات زر اعة الثر ايين التاجية.

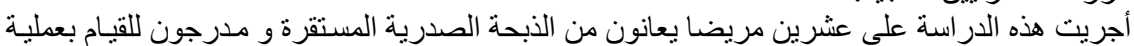

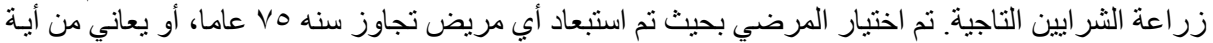

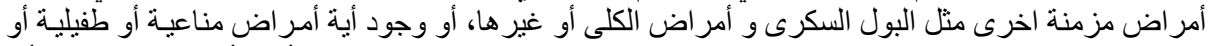

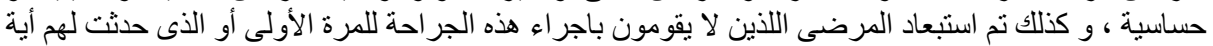
مضاعفات أو حمى بعد اجر اء العملية.

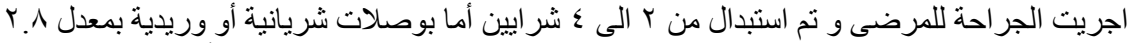

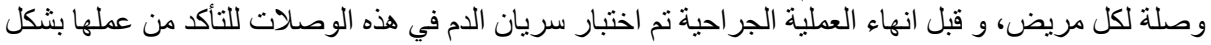

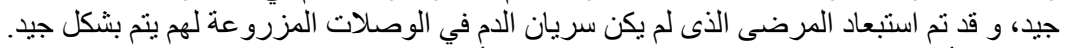

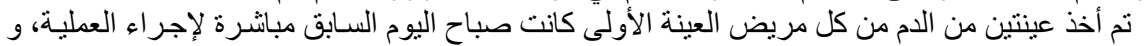

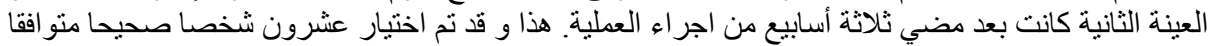

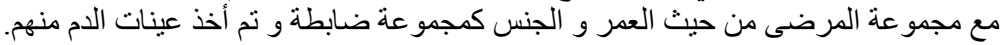

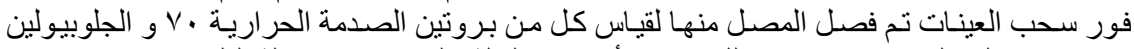

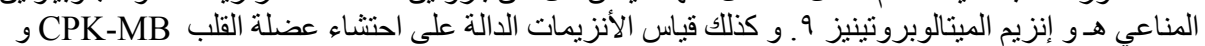

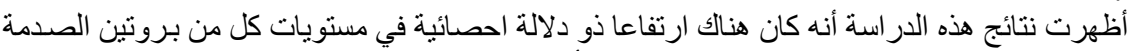
LDH

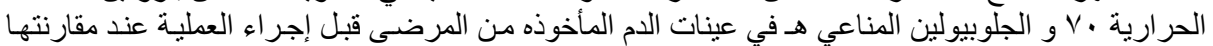

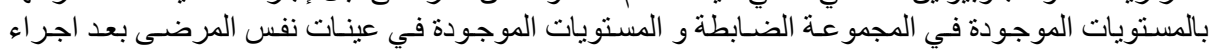

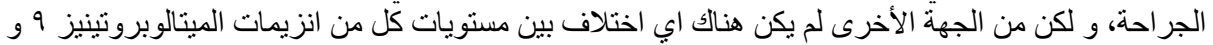

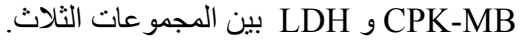

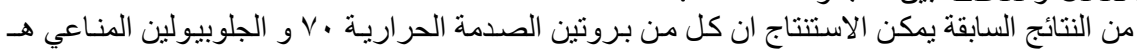

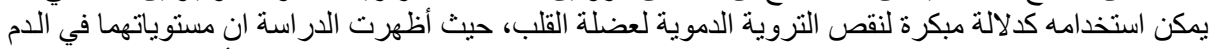

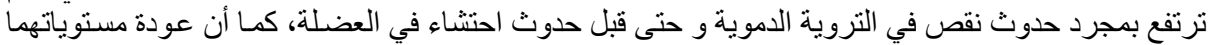

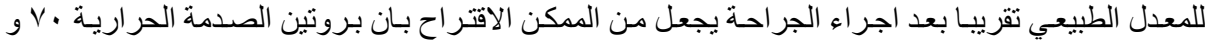

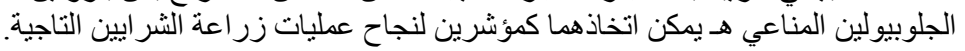

